\title{
Foxg1 Confines Cajal-Retzius Neuronogenesis and Hippocampal Morphogenesis to the Dorsomedial Pallium
}

\author{
Luca Muzio and Antonello Mallamaci \\ Department of Biological and Technological Research, San Raffaele Scientific Institute, 20132 Milan, Italy
}

It has been suggested that cerebral cortex arealization relies on positional values imparted to early cortical neuroblasts by transcription factor genes expressed within the pallial field in graded ways. Foxg1, encoding for one of these factors, previously was reported to be necessary for basal ganglia morphogenesis, proper tuning of cortical neuronal differentiation rates, and the switching of cortical neuroblasts from early generation of primordial plexiform layer to late production of cortical plate. Being expressed along a rostral/lateral ${ }^{\text {high }}$ to-caudal/medial ${ }^{\text {low }}$ gradient, Foxg1, moreover, could contribute to shaping the cortical areal profile as a repressor of caudomedial fates. We tested this prediction by a variety of approaches and found that it was correct. We found that overproduction of Cajal-Retzius neurons characterizing Foxg1 $1^{-1}$ mutants does not arise specifically from blockage of laminar histogenetic progression of neocortical neuroblasts, as reported previously, but rather reflects lateral-to-medial repatterning of their cortical primordium. Even if lacking a neocortical plate, Foxg1 ${ }^{-/-}$embryos give rise to structures, which, for molecular properties and birthdating profile, are highly reminiscent of hippocampal plate and dentate blade. Remarkably, in the absence of Foxg1, additional inactivation of the medial fates promoter Emx2, although not suppressing cortical specification, conversely rescues overproduction of Reelin ${ }^{\text {on }}$ neurons.

Key words: Foxg1; Emx2; Wnt types; hippocampus; neocortex; Cajal-Retzius cells

\section{Introduction}

Areal specification of cortical neurons is an extremely complex task, currently the subject of intensive experimental investigation. Such specification begins with the areal commitment of neuronal progenitors and is completed with the migration of newborn neurons from periventricular layers to their final laminar destination. Genetic control of this process is very sophisticated. Before the arrival of the thalamocortical radiation, it mainly relies on a complex interplay among diffusible ligands, released by signaling centers at the borders of the cortical morphogenetic field, and transcription factor genes, expressed by periventricular neuronal progenitors, gradually along the main coordinate axes of this field (Bishop et al., 2000; Mallamaci et al., 2000; Bulchand et al., 2001; Fukuchi-Shimogori and Grove, 2001, 2003; Monuki et al., 2001; Muzio et al., 2002a, 2005; Ohkubo et al., 2002; Theil et al., 2002; Vyas et al., 2003; Hamasaki et al., 2004; Shimogori et al., 2004).

Among telencephalic transcription factor genes, there is Foxg1, expressed from less than embryonic day 9.5 (E9.5) along a cortical rostral/lateral ${ }^{\text {high }}$-to-caudal/medial ${ }^{\text {low }}$ gradient and shown to be crucial for relevant aspects of CNS development, including basal ganglia morphogenesis and repression of cortical

Received Nov. 24, 2004; revised March 17, 2005; accepted March 19, 2005.

This work was funded by European Union Grants QLG3-CT-2000-00158 and QLG3-CT-2000-01625. We thank Drs. Susan McConnell, Peter Gruss, and H. Westphal for providing us with Foxg1, Emx2, and Lhx2 null founders, respectively.

Correspondence should be addressed to Antonello Mallamaci, Department of Biological and Technological Research, San Raffaele Scientific Institute, via Olgettina 58, 20132 Milan, Italy. E-mail: a.mallamaci@hsr.it. DOI:10.1523/JNEUROSCI.4804-04.2005

Copyright $\odot 2005$ Society for Neuroscience $\quad$ 0270-6474/05/254435-07\$15.00/0 neuronogenesis (Xuan et al., 1995; Dou et al., 1999; Seoane et al., 2004). More recently, Hanashima et al. (2004) reported that, in the absence of this gene, all cortical neurons express Reelin (Reln), a hallmark of preplate Cajal-Retzius cells, and the cortical neurons are negative for a large panel of markers peculiar to the cortical plate. On the basis of that finding, they proposed that Foxg1 is a key promoter of neocortical lamination, essential to neocortical neuroblasts in switching from preplate neuronogenesis to cortical plate neuronogenesis. Remarkably, in the wildtype telencephalon, Reln ${ }^{\text {on }}$ neurons are clustered tightly in the archicortex and arranged loosely in the neocortex and paleocortex, which reflects early confinement of their generation to the dorsomedial-most pallial primordium (Meyer et al., 2002; Takiguchi-Hayashi et al., 2004). Thus if the Foxg1 gradient is relevant to cortical arealization, overproduction of $\mathrm{Reln}^{\text {on }}$ neurons occurring in Foxg1 ${ }^{-1-}$ mutants may not be attributable to disrupted laminar histogenetic progression of their neocortical neuroblasts but, rather, may stem from large-scale lateral-tomedial repatterning of their cortical primordium. In support of this interpretation, we noticed that, of the cortical plate markers found to be absent by Hanashima et al. (2004), Foxp2, ROR $\beta$, and Otx 1 normally are confined to the neocortical plate, and Foxp1 is absent in the medial-most archicortical plate and dentate blade (Frantz et al., 1994; Ferland et al., 2003; Nakagawa and O'Leary, 2003). Thus we tested our hypothesis by a variety of experimental approaches and found that it was correct. In the absence of Foxg1, the entire cortical field is specified as cortical hem and archicortex, only a fraction of cortical neurons expresses Reln, and hippocampal plate-like and dentate blade-like structures develop in place of the missing neocortical plate. 


\section{Materials and Methods}

Animal husbandry and embryo harvesting. Brains for organotypic cultures were obtained from embryos of the C57BL/6 strain. Mutant embryos were generated by starting from Foxg1 null (Hébert and McConnell, 2000) Emx2 null (Pellegrini et al., 1996), and Lhx2 null (Porter et al., 1997) founders via appropriate breeding schemes. Parents of Foxg1 ${ }^{-/-}$ embryos were derived from founders of C57BL/6/129Sv mixed background through at least five passages of backcross to the C57BL/6 strain. Foxg1 $1^{-/+} E m \times 2^{-/+}$parents of Foxg1 ${ }^{-/-} E m x 2^{-/-}$embryos were obtained by crossing Foxg1 $1^{-/+}$and $E m \times 2^{-/+}$grandparents, which originated from founders of C57BL/6/129Sv mixed background through three and at least 10 passages of backcross to the C57BL/6 strain, respectively. Finally, Foxg1 $1^{-/+} \mathrm{Emx}^{-/+}$parents of Foxg1 $1^{-/-} \mathrm{Lh} x 2^{-/-}$embryos were obtained by crossing Foxg1 $1^{-/+}$and $L h x 2^{-/+}$grandparents, which originated from founders of C57BL/6/129Sv mixed background through five and two passages of backcross to the C57BL/6 strain, respectively. Animal husbandry and embryo harvesting were performed in compliance with European laws [European Communities Council Directive of November 24, 1986 (86/609/EEC)] and according to the guidelines of the H San Raffaele Institutional Animal Care and Use Committee.

Mouse genotyping. Mutant mice were genotyped by PCR as follows. For $E m \times 2$ mutants, the oligos include the following: E2F, 5' -CAC AAG TCC CGA GAG TTT CCT TTT GCA CAA CG-3', E2R/WT, 5'-ACC TGA GTT TCC GTA AGA CTG AGA CTG TGA GC- $3^{\prime}$, and $E 2 R / K O$, 5'-ACT TCC TGA CTA GGG GAG GAG TAG AAG GTG G-3'; the program includes $98^{\circ} \mathrm{C}$ for $5 \mathrm{~min}(1 \times), 98^{\circ} \mathrm{C}$ for $1 \mathrm{~min}$ and $72^{\circ} \mathrm{C}$ for 2 $\min (5 \times), 94^{\circ} \mathrm{C}$ for $1 \mathrm{~min}$ and $72^{\circ} \mathrm{C}$ for $2 \mathrm{~min}(30 \times)$, and $72^{\circ} \mathrm{C}$ for $10 \mathrm{~min}$ $(1 \times)$; the PCR products include $180 \mathrm{bp}$ (wild-type allele) and $340 \mathrm{bp}$ (null allele). For Foxg1 mutants, the oligos include the following: Bf1F25, 5' -GCC GCC CCC CGA CGC CTG GGT GAT G-3', Bf1-R159, $5^{\prime}$-TGG TGG TGG TGA TGA TGA TGG TGA TGC TGG-3', and BflRcre222, 5' -ATA ATC GCG AAC ATC TTC AGG TTC TGC GGG-3'; the program includes $98^{\circ} \mathrm{C}$ for $5 \min (1 \times), 98^{\circ} \mathrm{C}$ for $1 \mathrm{~min}, 65^{\circ} \mathrm{C}$ for $1 \mathrm{~min}$, and $72^{\circ} \mathrm{C}$ for $1.5 \mathrm{~min}(5 \times) ; 94^{\circ} \mathrm{C}$ for $1 \mathrm{~min}, 65^{\circ} \mathrm{C}$ for $1 \mathrm{~min}$, and $72^{\circ} \mathrm{C}$ for $1.5 \mathrm{~min}(30 \times)$; and $72^{\circ} \mathrm{C}$ for $10 \mathrm{~min}(1 \times)$. The PCR products include 186 bp (wild-type allele) and $220 \mathrm{bp}$ (null allele). For $L h \times 2$ mutants, the oligos include the following: $L 2-F, 5^{\prime}$-GGC TCC GGC CAT CAG CTC CGC CAT CGA C-3', L2-R/WT, $5^{\prime}$-GAG CAA AGT AGT GGA GAG TCA GGT CTG TGG AC-3', and $L 2-R / K O N, 5^{\prime}$-GCA GCG CAT CGC CTT CTA TCG CCT TCT TGA C- $3^{\prime}$; the program includes $98^{\circ} \mathrm{C}$ for $5 \mathrm{~min}$ $(1 \times), 98^{\circ} \mathrm{C}$ for $1 \mathrm{~min}, 62^{\circ} \mathrm{C}$ for $1 \mathrm{~min}$, and $72^{\circ} \mathrm{C}$ for $1.5 \mathrm{~min}(5 \times) ; 94^{\circ} \mathrm{C}$ for $1 \mathrm{~min}, 60^{\circ} \mathrm{C}$ for $1 \mathrm{~min}$, and $72^{\circ} \mathrm{C}$ for $1.5 \mathrm{~min}(30 \times)$; and $72^{\circ} \mathrm{C}$ for 10 $\min (1 \times)$. The PCR products include $380 \mathrm{bp}$ (wild-type allele) and 600 bp (null allele).

Organotypic cultures. Organotypic cultures of cerebral cortex explants were performed by the Stoppini method, with minor modifications, as described previously (Mallamaci et al., 2000).

Neuron birthdating. For in vivo birthdating experiments, $100 \mu \mathrm{g}$ of bromodeoxyuridine (BrdU) per gram of body weight was administered to pregnant dams by intraperitoneal injection. For in vitro birthdating experiments, $10 \mu \mathrm{g} / \mathrm{ml} \mathrm{BrdU}$ was added to the culture medium.

In situ hybridization. Radioactive and nonradioactive in situ hybridizations were performed as described previously (Mallamaci et al., 2000; Muzio et al., 2002b), and the following probes were used: $\alpha$-Crystallin (PCR-amplified; GenBank accession number AF039391; nucleotides 392-1192; a gift from N. Funatsu, Tokyo, Japan), Cad6 (PCR-amplified; GenBank accession number D82029; nucleotides 430-1230), Coup-tf1 (1.5 kb EcoRI-XhoI fragment from the plasmid Coup-Tf1; a gift from M. Studer, Naples, Italy), Cre (a $1.5 \mathrm{~kb}$ PstI-PstI fragment from the plasmid pIC-cre; a gift from Wolfgang Wurst, Munich, Germany), Dlx2 (plasmid M524; a gift from A. Bulfone, Milan, Italy), Emx2 [plasmid PR130; including $0.5 \mathrm{~kb}$ of the Emx2 5' -untranslated region (UTR)], Ephb1 (PCRamplified; GenBank accession number AK036211; nucleotides 3101-3774), Fzd8 (plasmid mFz8; a gift from S. Pleasure, San Francisco, CA), Fzd9 (PCR-amplified; GenBank accession number AC074359; nucleotides 924-1948), Id3 (PCR-amplified; GenBank accession number M60523; nucleotides 90-905), Lef1 (PCR-amplified; GenBank accession number NM_010703; nucleotides 1804-2544), Lhx2 (PCR-amplified;

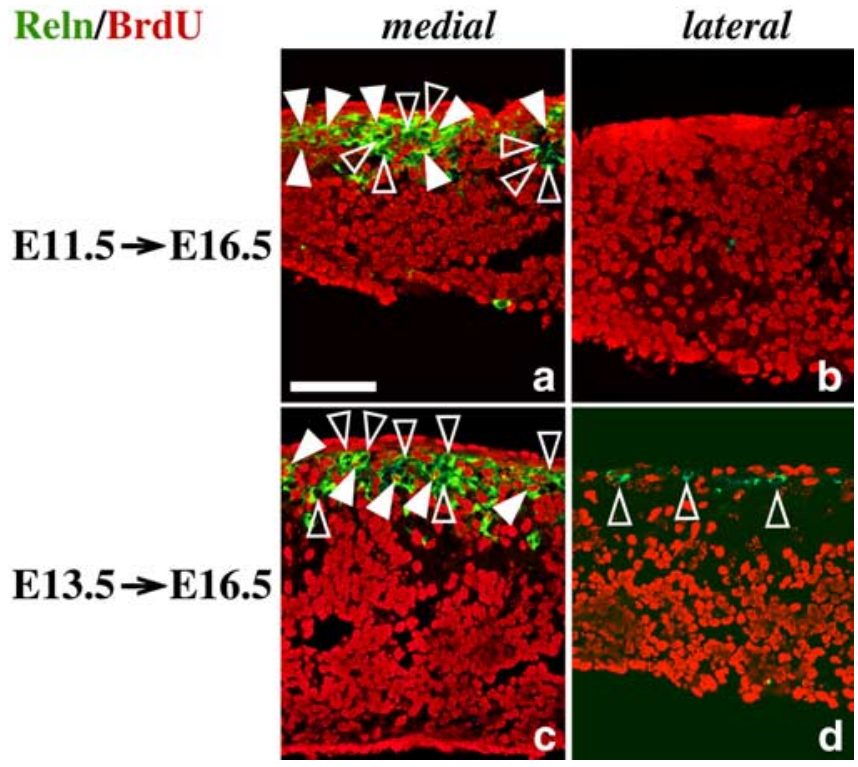

Figure 1. Areal commitment of Reln. The distribution of immunoreactivity against BrdU and Reln on radial sections of organotypic explants dissected out from wild-type, medial $(\boldsymbol{a}, \boldsymbol{c})$, and lateral $(\boldsymbol{b}, \boldsymbol{d})$ cortical primordia at $\mathrm{E} 11.5(\boldsymbol{a}, \boldsymbol{b})$ and $\mathrm{E} 13.5(\boldsymbol{c}, \boldsymbol{d})$ and allowed to develop in vitro up to the equivalent of E16.5 in the presence of saturating BrdU is shown. Marginal is to the top, and ventricular is to the bottom. Filled and open arrowheads point to Rel ${ }^{\text {on }}$ neurons labeled or not labeled by BrdU, respectively. Scale bar, $100 \mu \mathrm{m}$.

GenBank accession number NM010710.1; nucleotides 1128-1748), Lhx9 (plasmid pBSK-Lhx9; a gift from S. Bertuzzi, Washington, DC), Prox1 (plasmid Prox1/300; a gift from E. Grove, Chicago, IL), Reln (plasmid BS6; a gift from G. D'Arcangelo, Houston, TX), Steel (PCR-amplified; GenBank accession number NM013598; nucleotides 1118-3698), Tbr2 (plasmid D12; a gift from A. Bulfone, Milan, Italy), Ttr (PCRamplified; GenBank accession number D00071; nucleotides 13-1484), Wnt3a (PCR-amplified; GenBank accession number NM009522; nucleotides 29-1451), Wnt5a (PCR-amplified; GenBank accession number NT039598.1; nucleotides 1750730-1752109), and Wnt8b (PCR-amplified; GenBank accession numbers NM01172, AW488375, and AA874401; $1370 \mathrm{bp}$ fragment encompassing the last $488 \mathrm{bp}$ of coding sequence plus the first $882 \mathrm{bp}$ of the $3^{\prime}$-UTR).

Immunohistochemistry and immunofluorescence. Immunohistochemistry and immunofluorescence were performed as described previously (Mallamaci et al., 2000; Muzio et al., 2002b). The following primary antibodies were used: anti-Reln G10 mouse monoclonal antibody (1:300; a gift from A. Goffinet, Brussels, Belgium), anti-BrdU mouse monoclonal antibody (1:50; Becton Dickinson, Mountain View, CA), anti-Otx2 rabbit polyclonal antibody (1:500; a gift from G. Corte, Genua, Italy), anti-Emx1 rabbit polyclonal antibody (1:500; a gift from G. Corte, Genua, Italy), anti-GAD65/67, rabbit polyclonal (1:500; Chemicon, Temecula, CA), and anti-neurospecific class III $\beta$-tubulin, mouse monoclonal (1:1000; BabCo, Richmond, CA).

Photography and editing. Photographs were taken by a Nikon (Taunton, MA) Eclipse 600 microscope equipped with an SV Micro CV3000 digital microscope camera. Immunocolocalization studies were run on a Zeiss (Oberkochen, Germany) Axiophot microscope equipped with a Bio-Rad (Hercules, CA) confocal detection apparatus. Electronic files were processed on a MacIntoshG3 computer by Adobe Photoshop 6.0 software (Adobe Systems, San Jose, CA).

\section{Results}

To confirm that pallial generation of Reln ${ }^{\text {on }}$ neurons is confined mainly to the medial-most cerebral cortex, we dissected out medial and lateral portions of E11.5 and E13.5 wild-type cortical primordia, cultured them organotypically in the presence of saturating BrdU up to the equivalent of E16.5, and monitored the 


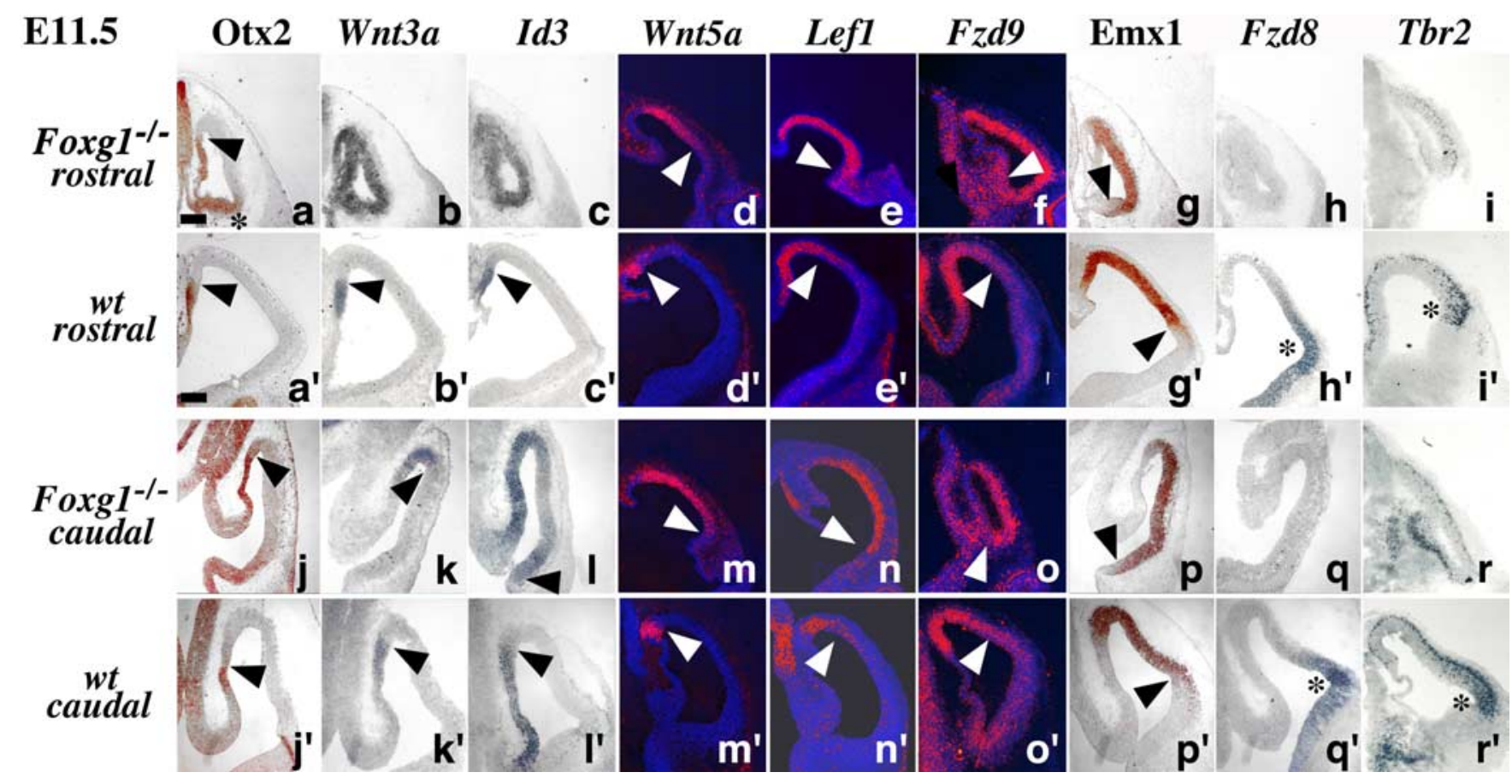

Figure 2. Regionalization of the early-neuronogenic Foxg $1^{-/-}$cortical primordium. The distribution of 0tx2 $\left(\boldsymbol{a}, \boldsymbol{a}^{\prime}, \boldsymbol{j}, \boldsymbol{j}^{\prime}\right)$, Wnt3a mRNA $\left(\boldsymbol{b}, \boldsymbol{b}^{\prime}, \boldsymbol{k}, \boldsymbol{k}^{\prime}\right), \operatorname{ld} 3 \mathrm{mRNA}\left(\boldsymbol{c}, \boldsymbol{c}^{\prime}, \boldsymbol{l}, \boldsymbol{I}^{\prime}\right)$, Wnt5a mRNA $\left(\boldsymbol{d}, \boldsymbol{d}^{\prime}\right.$, $\left.\boldsymbol{m}, \boldsymbol{m}^{\prime}\right)$, Lef1 mRNA $\left(\boldsymbol{e}, \boldsymbol{e}^{\prime}, \boldsymbol{n}, \boldsymbol{n}^{\prime}\right), F z d 9 \mathrm{mRNA}\left(\boldsymbol{f}, \boldsymbol{f}^{\prime}, \boldsymbol{0}, \boldsymbol{o}^{\prime}\right), \operatorname{Emx} 1\left(\boldsymbol{g}, \boldsymbol{g}^{\prime}, \boldsymbol{p}, \boldsymbol{p}^{\prime}\right), F z d 8 \mathrm{mRNA}\left(\boldsymbol{h}, \boldsymbol{h}^{\prime}, \boldsymbol{q}, \boldsymbol{q}^{\prime}\right)$, and Tbr2 mRNA $\left(\boldsymbol{i}, \boldsymbol{i}^{\prime}, \boldsymbol{r}, \boldsymbol{r}^{\prime}\right)$ on rostral $\left(\boldsymbol{a}-\boldsymbol{i}^{\prime}\right)$ and caudal $\left(\boldsymbol{j}-\boldsymbol{r}^{\prime}\right)$ frontal sections of Foxg $1^{-/}$ $(\boldsymbol{a}-\boldsymbol{r})$ and wild-type $\left(\boldsymbol{a}^{\prime}-\boldsymbol{r}^{\prime}\right)$ E11.5 telencephalons is shown. Arrowheads in $\boldsymbol{a}-\boldsymbol{g}^{\prime}$ and $\boldsymbol{j}-\boldsymbol{o}^{\prime}$ point to the ventrolateral border of each pallial expression domain. The asterisk in $\boldsymbol{a}$ corresponds to the rostroventral 0 tx2 expression subdomain peculiar to $F o x g 1^{-1-}$ mutants. Asterisks in $\boldsymbol{h}^{\prime}, \boldsymbol{i}^{\prime}, \boldsymbol{q}^{\prime}$, and $\boldsymbol{r}^{\prime}$ demarcate lateral ventricular expression domains of $F z d 8$ and $T b r 2$, specific to wild-type brains. Scale bars, $200 \mu \mathrm{m}$.

distribution of immunoreactivity against Reln and BrdU on radial sections of these explants. Numerous Reln ${ }^{\text {on }}$ neurons could be detected specifically in both E11.5 and E13.5 medial explants, only a few in E13.5 lateral explants, and almost none in E11.5 lateral ones. A substantial fraction of Reln ${ }^{\text {on }}$ neurons within medial explants was also immunopositive for BrdU; no Reln ${ }^{\text {on }} \mathrm{Br}-$ $\mathrm{dU}^{\text {on }}$ neurons could be detected in lateral explants at all (Fig. 1). This meant that, as expected, the early medial cortex is committed specifically to the generation of Reln ${ }^{\text {on }}$ neurons. Moreover, it suggested that a large fraction of cortical Reln ${ }^{\text {on }}$ neurons would be born within the medial cortex, between less than E11.5 and E13.5, and that part of them would migrate to the lateral cortex after E11.5.

Then to assess functional relevance of Foxg1 to telencephalic regionalization, we first scored Foxg1 null brains for distribution of selected molecular markers at E11.5, when the boundaries among the main telencephalic subdivisions are morphologically evident and molecular regionalization of the pallial anlage is established clearly. We were not able to detect any expression of subpallial markers such as glutamic decarboxylases 65/67 (data not shown), thus confirming previous reports of ganglionic eminence agenesy in these mutants (Xuan et al., 1995; Dou et al., 1999). Conversely, the dorsomedial Otx2 expression domain became enlarged (Fig. $2 a, a^{\prime}, j, j^{\prime}$ ), suggesting that the boundary between the cortical hem and the cortical field was displaced laterally. Wnt $3 a, I d 3, W n t 5 a, L e f 1$, and Fzd9, normally confined to the archicortical anlage, spread into the more lateral pallium (Fig. $\left.2 b-f^{\prime}, k-o^{\prime}\right)$; Emxl was displaced laterally, up to the junction between cortical and ocular fields peculiar to these mutants (Fig. $\left.2 g, g^{\prime}, p, p^{\prime}\right)$; ventricular Tbr2 and Fzd8, normally restricted to the lateroventral pallium, were downregulated or undetectable (Fig. $\left.2 h-i^{\prime}, q-r^{\prime}\right)$. All of that pointed to a dramatic enlargement of presumptive archicortex at the expense of the neocortex and paleo- cortex. Molecular profiling of the Foxg1 ${ }^{-1-}$ cortex 3 d later, at E14.5, gave consistent results. The $\mathrm{Ttr}^{\text {off }} \mathrm{Ot} \times 2^{\text {on }} \mathrm{Foxg} 1^{\text {off }} \mathrm{Lh} \times 2^{\text {off }}$ domain, corresponding to the cortical hem, was expanded substantially on rostral sections and enlarged slightly at more caudal levels (Fig. $3 a-h^{\prime}$ ). Emxl and the dorsomedial markers Id3, Wnt3a, Wnt8b, Fzd9, and Emx2 were expressed intensely throughout the cortical field, which thus acquired molecular features very similar to those of the medial-most hippocampal field at this stage (Fig. $3 i-n^{\prime}$ ). At E16.5 the dentate gyrus (DG) marker Prox1 (Torii et al., 1999), previously activated at E14.5 (supplemental Fig. S2, available at www.jneurosci.org as supplemental material), and the hippocampal plate marker $\alpha$-Crystallin (Funatsu et al., 2004) were both detectable throughout periventricular layers of the mutant telencephalon; the former one was also in a larger region near the dorsal edge of it (Fig. 3o- $p^{\prime}$ ). Finally, at E19.5, this resulted in the development of a shield-like structure, with striking topological molecular similarities to the wild-type perinatal hippocampus (Fig. 4o, $o^{\prime}$ ). Like the wild-type hippocampus, this structure was characterized by complementary distribution of Reln, a marker of the stratum lacunosummoleculare, and Coup-t $f 1$, normally confined to nonmarginal layers of the developing cortex (Fig. $4 f, f^{\prime}$ ) (also see supplemental Fig. S1, available at www.jneurosci.org as supplemental material). As indicated by the distribution of neurospecific class III $\beta$-tubulin and by the BrdU uptake profile (Fig. $4 b, b^{\prime}, d, d^{\prime}$ ), this structure included a thick, marginal postmitotic neuronal layer and a thin, ventricular proliferative layer. Within the former, four subfields could be distinguished. The marginal, widest one expressed Reln (Fig. 4e,e $e^{\prime}$ ). The three deeper and smaller ones, in dorsal-to-ventral order, were positive for the DG markers Steel, Lhx9, Ephb1, and Prox1, respectively (Fig. $4 g-j^{\prime}$ ), the CA3 marker KA1 (Fig. $4 m, m^{\prime}$ ), and the subicular CA1 marker Cad6 (Fig. 


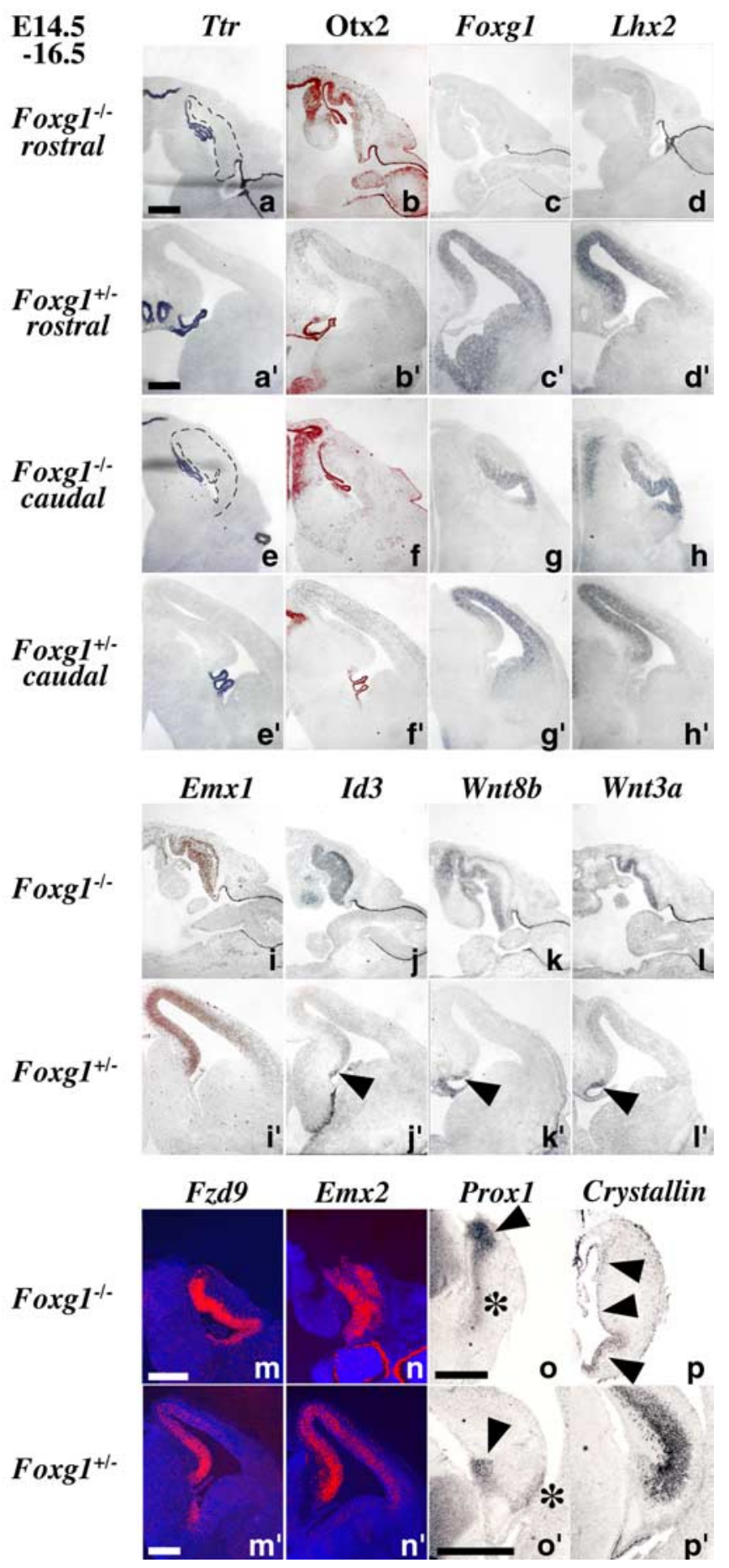

Figure 3. Regionalization of the mid-neuronogenic Foxg1 ${ }^{-1-}$ cortical primordium. The distribution of $\operatorname{TtrmRNA}\left(\boldsymbol{a}, \boldsymbol{a}^{\prime}, \boldsymbol{e}, \boldsymbol{e}^{\prime}\right), 0 \operatorname{tx2}\left(\boldsymbol{b}, \boldsymbol{b}^{\prime}, \boldsymbol{f}, \boldsymbol{f}^{\prime}\right)$, Foxg1 promoter-driven cre mRNA $\left(\boldsymbol{c}, \boldsymbol{c}^{\prime}\right.$, $\left.\boldsymbol{g}, \boldsymbol{g}^{\prime}\right)$, Lhx2 mRNA $\left(\boldsymbol{d}, \boldsymbol{d}^{\prime}, \boldsymbol{h}, \boldsymbol{h}^{\prime}\right)$, Emx1 $\left(\boldsymbol{i}, \boldsymbol{i}^{\prime}\right)$, Id3 mRNA $\left(\boldsymbol{j}_{\boldsymbol{j}} \boldsymbol{j}^{\prime}\right)$, Wnt8b mRNA $\left(\boldsymbol{k}, \boldsymbol{k}^{\prime}\right)$, Wnt3a $\operatorname{mRNA}\left(\boldsymbol{I}, \boldsymbol{I}^{\prime}\right)$, Fzd9mRNA $\left(\boldsymbol{m}, \boldsymbol{m}^{\prime}\right), \operatorname{Em} x 2 \mathrm{mRNA}\left(\boldsymbol{n}, \boldsymbol{n}^{\prime}\right), \operatorname{Prox} 1 \mathrm{mRNA}\left(\boldsymbol{0}, \boldsymbol{o}^{\prime}\right)$, and $\alpha$-Crystallin mRNA (p, $\left.\boldsymbol{p}^{\prime}\right)$ on frontal sections of Foxg $1^{-/-}(\boldsymbol{a}-\boldsymbol{p})$ and Foxg $1^{+/-}\left(\boldsymbol{a}^{\prime}-\boldsymbol{p}^{\prime}\right)$ E14.5 $\left(\boldsymbol{a}-\boldsymbol{n}^{\prime}\right)$ and E16.5 (o- $\left.\boldsymbol{p}^{\prime}\right)$ telencephalons is shown. Arrowheads in $\boldsymbol{j}^{\prime}-\boldsymbol{I}^{\prime}$ point to the dorsomedial-most cortex where $I d 3$, Wnt8b, and Wnt3a are normally confined. In $\boldsymbol{0}$ and $\boldsymbol{o}^{\prime}$, arrowheads and asterisks indicate DG and ventricular subdomains of Prox1, respectively. Arrowheads in $p$ point to the ventricular $\alpha$-Crystallin expression domain, peculiar to Foxg $1^{-1-}$ brains. Scale bars, $500 \mu \mathrm{m}$.

$\left.4 n, n^{\prime}\right)$. The pan-hippocampal plate marker $\alpha$-Crystallin was still expressed throughout the telencephalic ventricular zone; however, at this age, numerous neurons expressing it could also be detected at more marginal levels (Fig. $4 k-l^{\prime}$ ). Finally, as suggested by the BrdU uptake profile and expression pattern of the proliferative marker Tbr2, proliferative activity, like in the wild-type hippocampus, was not confined strictly to periventricular layers but also was detectable at more marginal, including subpial, levels (Fig. $4 b-c^{\prime}$ ). In summary, at all developmental stages that were the subject of analysis, overproduction of Reln ${ }^{\text {on }}$ neurons peculiar to Foxg1 $1^{-1-}$ embryos was associated closely with ectopic activation of hippocampal morphogenetic programs, which, in the absence of Foxg1, spread into the entire residual telencephalic primordium. Moreover, additional inactivation of the transcription factor gene Emx2, necessary for proper execution of dorsomedial programs (Bishop et al., 2000; Mallamaci et al., 2000; Muzio et al., 2002a; Shinozaki et al., 2002, 2004; Muzio and Mallamaci, 2003) although not suppressing cortical specification (Fig. $5 a-d^{\prime \prime}$ ), rescued neuronal overexpression of Reln (Fig. $5 e-$ $f^{\prime \prime}$ ), in agreement with the hypothesis that this phenotype may stem from a pallial regionalization error.

Finally, to assess whether Reln overexpression peculiar to Foxg1 null mutants is also enhanced by an impairment of the ability of neuroblasts to switch from preplate to cortical plate generation, we compared laminar histogenetic potencies of Foxg1 $1^{-/-}$and wild-type archicortical neuroblasts at E13.5 (i.e., the peak neuronogenesis time for the deep cortical plate). Remarkably, not the vast majority but only a small percentage of Foxg1 $1^{-1-}$ neurons born at E13.5 $(18.0 \pm 2.4 \% ; n=3)$ expressed Reln at E19.0 (Fig. 6), not far from the corresponding percentage measurable within the wild-type hippocampus $(8.7 \pm 2.1 \%$; $n=$ $3)$. This suggested that mutant cortical neuroblasts did not stop in their progression from preplate neuronogenesis to cortical plate neuronogenesis and that, rather, all of them behaved like wildtype archicortical neuroblasts.

\section{Discussion}

We have shown that during early cerebral cortex development, the generation of Reln ${ }^{\text {on }}$ neurons is confined mainly to the dorsomedial-most cortical wall, so overproduction of these cells occurring in Foxg1 ${ }^{-1-}$ mutants may be a consequence of lateralto-medial repatterning of their cortical primordium. We found that in the absence of Foxg1, the entire cortical field is specified as cortical hem and archicortex, many but not all cortical neurons express Reln, and hippocampal plate-like as well as dentate bladelike structures develop in place of the missing neocortical plate. Moreover, we have shown that additional inactivation of another transcription factor gene promoting caudomedial corticogenesis, Emx2, rescues the overproduction of Reln ${ }^{\text {on }}$ neurons. Finally, we found that in Foxg1 $1^{-/}$mutants, the shift from preplate neuronogenesis to cortical plate neuronogenesis is not suppressed, suggesting that Foxg1 is not absolutely necessary for laminar histogenetic progression of cortical neuroblasts.

Specific commitment of the dorsomedial cortical neuroepithelium to the generation of Reln ${ }^{\text {on }}$ Cajal-Retzius cells, emerging from our analysis of cortical explants, is not novel. A presumptive source of Cajal-Retzius cells, spreading all over the cortex, was described in the human medial cortical wall starting from E55, on the basis of time course analysis of Reln and p73 expression (Meyer et al., 2002). More recently, in the mouse these cells have been traced during their tangential migration from the cortical hem to the neocortex, with the exo utero somatic electroporation of a green fluorescent protein-encoding transgene (TakiguchiHayashi et al., 2004). On the contrary, our results differ from what Hanashima et al. (2004) recently reported about cortical development in Foxg1 ${ }^{-/-}$mutants. In contrast to these authors, we found that, in the absence of Foxg1, not all neurons express 

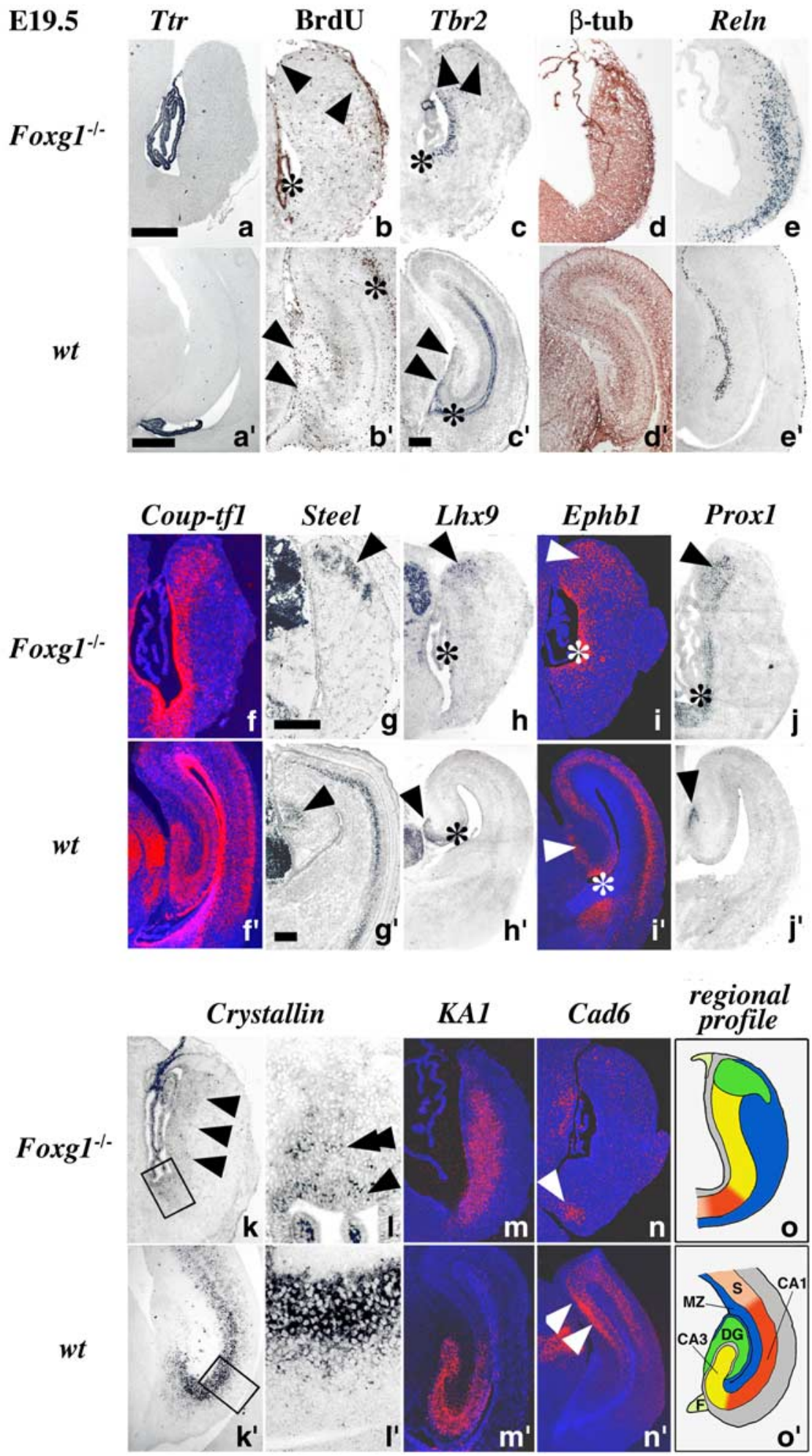

Figure 4. Regionalization of the late-neuronogenic Foxg $1^{-/-}$cortical primordium. The distribution of $\operatorname{Ttr}\left(\boldsymbol{a}, \boldsymbol{a}^{\prime}\right), \operatorname{BrdU}\left(\boldsymbol{b}, \boldsymbol{b}^{\prime}\right), \operatorname{Tbr} 2 \mathrm{mRNA}(\boldsymbol{c}$, $\left.\boldsymbol{c}^{\prime}\right)$, neurospecific class III $\beta$-tubulin $\left(\boldsymbol{d}, \boldsymbol{d}^{\prime}\right)$, Reln mRNA $\left(\boldsymbol{e}, \boldsymbol{e}^{\prime}\right)$, Coup-tf1 mRNA $\left(\boldsymbol{f}, \boldsymbol{f}^{\prime}\right)$, SteelmRNA $\left(\boldsymbol{g}, \boldsymbol{g}^{\prime}\right)$, Lhx9mRNA $\left(\boldsymbol{h}, \boldsymbol{h}^{\prime}\right)$, Ephb1 mRNA $\left(\boldsymbol{i}, \boldsymbol{i}^{\prime}\right)$, Prox1mRNA $\left(\mathbf{j} \boldsymbol{j}^{\prime}\right), \alpha$-CrystallinmRNA $\left(\boldsymbol{k}-\boldsymbol{l}^{\prime}\right), K A 1 \mathrm{mRNA}\left(\boldsymbol{m}, \boldsymbol{m}^{\prime}\right)$, and Cad6mRNA $\left(\boldsymbol{n}, \boldsymbol{n}^{\prime}\right)$ on brainsfrom Foxg ${ }^{-/}(\boldsymbol{a}-\boldsymbol{n})$ and wild-type $\left(\boldsymbol{a}^{\prime}-\boldsymbol{n}^{\prime}\right)$ E19.5 (a- $\left.\boldsymbol{f}^{\prime}, \boldsymbol{h}-\boldsymbol{n}^{\prime}\right)$ and E16.5 $\left(\boldsymbol{g}, \boldsymbol{g}^{\prime}\right)$ embryos, terminally pulsed by BrdU is shown. In/and $\boldsymbol{l}^{\prime}$, high-powermagnifications ofboxedareas in $\boldsymbol{k}$ and $\boldsymbol{k}^{\prime}$ are shown. In $\boldsymbol{b}-\boldsymbol{c}^{\prime}$, arrowheads point to subpial BrdU uptake domains and Tbr2 expression domains, respectively; asterisks demarcate their corresponding ventricular counterparts. In $\mathbf{g}-\boldsymbol{j}^{\prime}$, arrowheads indicate DG expression domains of Steel, Lhx9, Ephb1, and Prox1; asterisks demarcate the corresponding domains within the archicortical primary proliferative matrix. In $\boldsymbol{k}$, arrowheads indicate periventricular regions of the Foxg ${ }^{-/-}$ telencephalon expressing $\alpha$-Crystallin; in Iand $I^{\prime}$, an arrowhead and a double arrowhead point to $\alpha$-Crystallin-expressing cells within ventricular and subventricular regions of the mutant telencephalon, respectively. In $\boldsymbol{n}$ and $\boldsymbol{n}^{\prime}$, arrowheads point to the subicular-CA1 Cad6 expression subdomain. In $\mathbf{0}$ and $\boldsymbol{o}^{\prime}$, a schematic representation of the regionalization profile of the E19.5 Foxg1 null telencephalon is shown compared with the wild-type hippocampus. CA1, CA3, CA fields; F, fimbria; MZ, marginal zone; S, subiculum. Scale bars, $200 \mu \mathrm{m}$.
Reln, and a cortical plate-like structure with hippocampal features is laid down. We also found that $<20 \%$ of E13.5 born mutant neurons differentiated as CajalRetzius cells, whereas the remainder mainly settled within $\alpha$-Crystallin/KA1rich layers of the mutant cortex. All of this suggests that Foxg1 is not absolutely necessary to switch from preplate neuronogenesis to cortical plate neuronogenesis and that the overproduction of Reln ${ }^{\text {on }}$ neurons occurring in Foxg1 $1^{-/-}$brains may arise from an areal patterning error. Moreover, the higher frequency at which cortical neuroblasts seem to differentiate to CajalRetzius cells in the Foxg1 ${ }^{-/-}$telencephalon compared with wild-type archicortex $(18.0 \pm 2.4$ vs $8.7 \pm 2.1 \%)$ may be apparent only because of the pronounced tangential dilution these cells specifically undergo during normal cerebral cortex development, and not in Foxg1 ${ }^{-1-}$ brains. If it is so, the relevance of Foxg1 to laminar histogenetic progression of cortical neuroblasts is very poor, and the reversion of late cortical neuroblasts to Cajal-Retzius cells neuronogenesis, occurring with conditional ablation of Foxgl at E13 (Hanashima et al., 2004), is an epiphenomenon of an unforeseen (Tole and Grove, 2001) areal plasticity of the cortical primordium. Remarkably, this interpretation is consistent with the results of our time course dorsoventral profiling of Foxg1 $1^{-/-}$ brains. In fact, at the onset of cortical neuronogenesis the entire telencephalon of Foxg $1^{-1-}$ mutants is specified abnormally as the medial pallium (i.e., the anlage of Cajal-Retzius cells and medial hippocampus), and, subsequently, its spatiotemporal molecular profile evolves like that of the wild-type archicortex. Interestingly, regional colocalization of Ephb1, Proxl, $\alpha$-Crystallin, and KA1 mRNAs in the ventricular zone of the Foxg1 ${ }^{-/-}$telencephalon (Fig. $4 i-k^{\prime}, m, m^{\prime}$ ) as well as the presence of presumptive newborn Reln ${ }^{\text {on }}$ neurons throughout its periventricular layers (supplemental Fig. S1, available at www.jneurosci.org as supplemental material) (data not shown) also suggests that the same progenitors could give rise to all of the three main neuronal types originating from the dorsal-most cortical primordium, Cajal-Retzius neurons, DG granules, and hippocampal pyramids, which subsequently would segregate as summarized in Figure 4, $o$ and $o^{\prime}$.

Thus Foxg1 has to be included into the growing group of transcription factor genes controlling early steps of cerebral cortex arealization (O'Leary and Nakagawa, 2002), as a key repressor of dorso- 
medial differentiation programs. In this context, its activity partly resembles that of Lhx2. Like Foxg1, Lhx2 confines cortical hem fates to the dorsomedial edge of the pallial field (Bulchand et al., 2001; Monuki et al., 2001), limits Cajal-Retzius cell production to this region (Monuki et al., 2001), and inhibits choroid plexus morphogenesis (actually, this last activity can be appreciated more easily by looking at Foxg $1^{-1-} L h \times 2^{-/-}$double mutants) (data not shown). However, the genetic program specifying the archicortex, activated throughout the telencephalic vesicle of Foxg $1^{-/-}$brains, aborts in $L h \times 2^{-/-}$brains (Bulchand et al., 2001), suggesting that Lhx2, but not Foxg1, is required for development of the hippocampus. Moreover, it has been shown that early activation of Wnt signaling around the cortical hem primes the surrounding pallium to execute hippocampal morphogenetic programs (Shimogori et al., 2004). Thus Foxg1 normally may inhibit ectopic, neopallial activation of these programs simply by downregulating Wnt genes (Figs. 2b, $b^{\prime}, k, k^{\prime}, d, d^{\prime}, m, m^{\prime}, 3 k-l^{\prime}$ ) (Theil et al., 2002) and desensitizing the intermediate cortical field to their activity (Galceran et al., 1999) (Figs. $2 e, e^{\prime}, n, n^{\prime}, f, f^{\prime}, o, o^{\prime}, 3 m, m^{\prime}$ ). It has also been shown that a mutually stimulating loop involving Emx2 and canonical Wnt signaling takes place in the anlage of the occipital cortex and hippocampus (Muzio et al., 2005). Therefore, Wnt inhibition may also be sustained by Foxg1-dependent confinement of Emx2 to the dorsomedial-most pallium (Dou et al., 1999) (Fig. $3 n, n^{\prime}$ ), achieved via downregulation of its positive regulator BMP4 (bone morphogenetic protein 4) (Dou et al., 1999; Ohkubo et al., 2002; Theil et al., 2002) and the abovementioned depression of the $\mathrm{Wnt} / \beta$-catenin axis.

Finally, beyond the involvement of Foxg1 in pallial arealization, it has to be emphasized that a true hippocampal plate does not develop in Foxg1 ${ }^{-1-}$ brains. Reln off neurons expressing Coup-tf1, $\alpha$-Crystallin, and KA1 are confined mainly to periventricular layers; they fail to migrate to more marginal locations and do not coalesce into a morphologically distinct plate (Fig. $4 f, f^{\prime}, k-$ $\left.l^{\prime}\right)$. This may be attributable to Reln overexpression peculiar to Foxg1 ${ }^{-1-}$ mutants as well as to misconfiguration of their radial glia (data not shown). However, lower $\alpha$-Crystallin and KAl expression levels detectable in mutant compared with wild-type brains suggest that Foxg1, even if not crucial for the switch from preplate to cortical plate neuronogenesis, nevertheless may be necessary to sustain full differentiation of non-Cajal-Retzius cells to pyramidal types. Much work is still necessary to clarify this point as well as to reconstruct fine molecular mechanisms by which Foxg1 shapes the cortical areal profile.

\section{References}

Bishop KM, Goudreau G, O'Leary DDM (2000) Regulation of area identity in the mammalian neocortex by Emx2 and Pax6. Science 288: $344-349$.

Bulchand S, Grove EA, Porter FD, Tole S (2001) LIM-homeodomain gene Lhx2 regulates the formation of the cortical hem. Mech Dev 100:165-175.

Dou CL, Li S, Lai E (1999) Dual role of brain factor-1 in regulating growth and patterning of the cerebral hemispheres. Cereb Cortex 9:543-550.

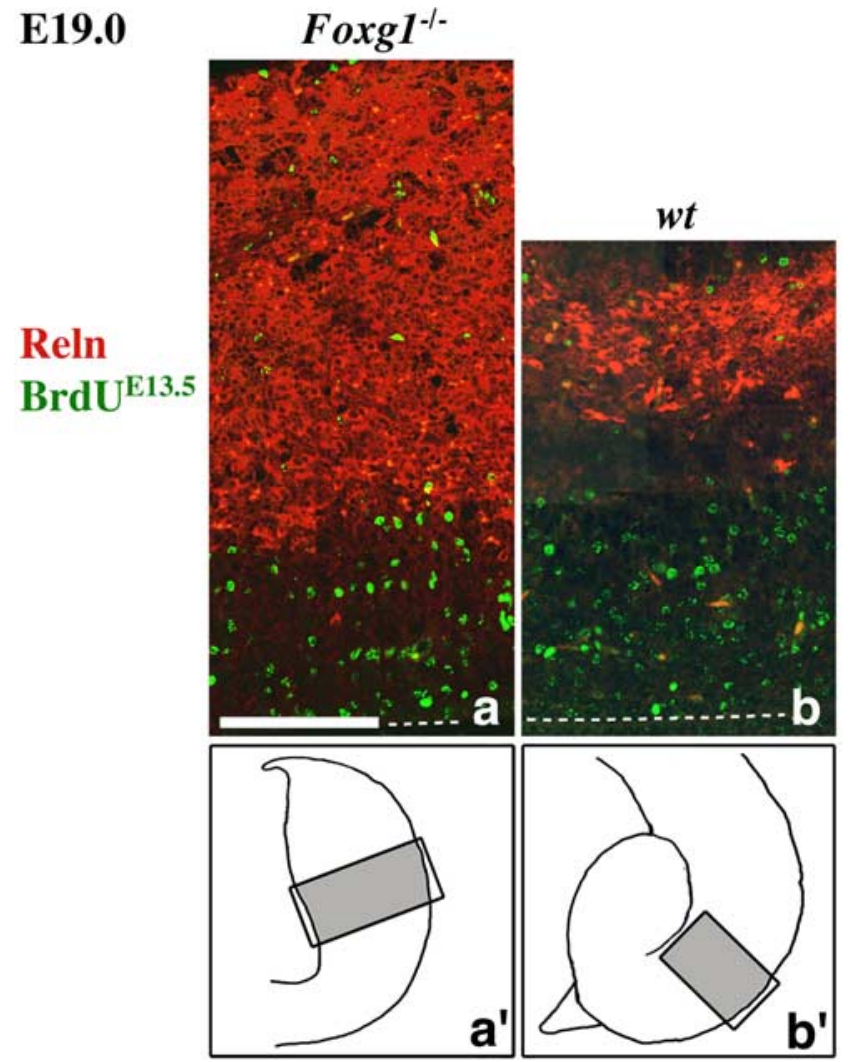

Figure 6. Neuronal birthdating in the Foxg $1^{-1-}$ cortical primordium. The distribution of BrdU (green) and Reln (red) on frontal telencephalic sectors of E19.0 Foxg $1^{-1-}($ a $)$ and wildtype (b) embryos, pulsed by BrdU at E13.5 is shown; ventricular is to the bottom and marginal is to the top. In $\boldsymbol{a}$ and $\boldsymbol{b}$, the dashed lines indicate the ventricular border of the cortical wall. In $\boldsymbol{a}^{\prime}$ and $\boldsymbol{b}^{\prime}$, the silhouettes of the two telencephalons are shown, with boxes demarcating the sectors represented in $\boldsymbol{a}$ and $\boldsymbol{b}$, respectively. Scale bar, $100 \mu \mathrm{m}$.

Ferland RJ, Cherry TJ, Preware PO, Morrisey EE, Walsh CA (2003) Characterization of Foxp2 and Foxp1 mRNA and protein in the developing and mature brain. J Comp Neurol 460:266-279.

Frantz GD, Weimann JM, Levin ME, McConnell SK (1994) Otx1 and Otx2 
define layers and regions in developing cerebral cortex and cerebellum. J Neurosci 14:5725-5740.

Fukuchi-Shimogori T, Grove EA (2001) Neocortex patterning by the secreted signaling molecule FGF8. Science 294:1071-1074.

Fukuchi-Shimogori T, Grove EA (2003) Emx2 patterns the neocortex by regulating FGF positional signaling. Nat Neurosci 6:825-831.

Funatsu N, Inoue T, Nakamura S (2004) Gene expression analysis of the late embryonic mouse cerebral cortex using DNA microarray: identification of several region- and layer-specific genes. Cereb Cortex 14:1031-1044.

Galceran J, Farinas I, Depew MJ, Clevers H, Grosschedl R (1999) Wnt3a ${ }^{-1-}$ like phenotype and limb deficiency in $L e f 1^{-1-} \mathrm{Tcfl}^{-1-}$ mice. Genes Dev 13:709-717.

Hamasaki T, Leingartner A, Ringstedt T, O'Leary DDM (2004) EMX2 regulates sizes and positioning of the primary sensory and motor areas in neocortex by direct specification of cortical progenitors to high caudalmedial gradient. Neuron 43:359-372.

Hanashima C, Li SC, Shen L, Lai E, Fishell G (2004) Foxg1 suppresses early cortical cell fate. Science 303:56-59.

Hébert JM, McConnell SK (2000) Targeting of cre to the Foxg1 (BF-1) locus mediates loxP recombination in the telencephalon and other developing head structures. Dev Biol 222:296-306.

Mallamaci A, Muzio L, Chan CH, Parnavelas J, Boncinelli E (2000) Area identity shifts in the early cerebral cortex of $E m \times 2^{-1-}$ mutant mice. Nat Neurosci 3:679-686.

Meyer G, Perez-Garcia CG, Abraham H, Caput D (2002) Expression of p73 and Reelin in the developing human cortex. J Neurosci 22:4973-4986.

Monuki ES, Porter FD, Walsh CA (2001) Patterning of the dorsal telencephalon and cerebral cortex by a roof plate-Lhx2 pathway. Neuron 32:591-604.

Muzio L, Mallamaci A (2003) Emx1, Emx2, and Pax6 in specification, regionalization, and arealization of the cerebral cortex. Cereb Cortex 13:641-647.

Muzio L, DiBenedetto B, Stoykova A, Boncinelli E, Gruss P, Mallamaci A (2002a) Emx2 and Pax6 control regionalization of the pre-neuronogenic cortical primordium. Cereb Cortex 12:129-139.

Muzio L, DiBenedetto B, Stoykova A, Boncinelli E, Gruss P, Mallamaci A (2002b) Conversion of cerebral cortex into basal ganglia in $E m \times 2^{-1-}$ Pax6 ${ }^{\text {Sey/Sey }}$ double-mutant mice. Nat Neurosci 5:737-745.

Muzio L, Soria JM, Pannese M, Piccolo S, Mallamaci A (2005) A mutually stimulating loop involving Emx2 and canonical Wnt signaling specifically promotes expansion of occipital cortex and hippocampus. Cereb Cortex, in press.

Nakagawa Y, O'Leary DDM (2003) Dynamic patterned expression of orphan nuclear receptor genes $R O R \alpha$ and $R O R \beta$ in developing mouse forebrain. Dev Neurosci 25:234-244.
Ohkubo Y, Chiang C, Rubenstein JL (2002) Coordinate regulation and synergistic actions of BMP4, SHH, and FGF8 in the rostral prosencephalon regulate morphogenesis of the telencephalic and optic vesicles. Neuroscience 111:1-17.

O'Leary DD, Nakagawa Y (2002) Patterning centers, regulatory genes, and extrinsic mechanisms controlling arealization of the neocortex. Curr Opin Neurobiol 12:14-25.

Pellegrini M, Mansouri A, Simeone A, Boncinelli E, Gruss P (1996) Dentate gyrus formation requires Emx2. Development 122:3893-3898.

Porter FD, Drago J, Xu Y, Cheema SS, Wassif C, Huang SP, Lee E, Grinberg A, Massalas JS, Bodine D, Alt F, Westphal H (1997) Lhx2, a LIM homeobox gene, is required for eye, forebrain, and definitive erythrocyte development. Development 124:2935-2944.

Seoane J, Le HV, Shen L, Anderson SA, Massague J (2004) Integration of Smad and Forkhead pathways in the control of neuroepithelial and glioblastoma cell proliferation. Cell 117:211-223.

Shimogori T, Banuchi V, Ng HY, Strauss JB, Grove EA (2004) Embryonic signaling centers expressing BMP, WNT, and FGF proteins interact to pattern the cerebral cortex. Development 131:5639-5647.

Shinozaki K, Miyagi T, Yoshida M, Miyata T, Ogawa M, Aizawa S, Suda Y (2002) Absence of Cajal-Retzius cells and subplate neurons associated with defects of tangential cell migration from ganglionic eminence in Emx1/2 double mutant cerebral cortex. Development 129:3479-3492.

Shinozaki K, Yoshida M, Nakamura M, Aizawa S, Suda Y (2004) Emxl and Emx2 cooperate in initial phase of archipallium development. Mech Dev 121:475-489.

Takiguchi-Hayashi K, Sekiguchi M, Ashigaki S, Takamatsu M, Hasegawa H, Suzuki-Migishima R, Yokoyama M, Nakanishi S, Tanabe Y (2004) Generation of reelin-positive marginal zone cells from the caudomedial wall of telencephalic vesicles. J Neurosci 24:2286-2295.

Theil T, Aydin S, Koch S, Grotewold L, Ruther U (2002) Wnt and Bmp signaling cooperatively regulate graded $E m \times 2$ expression in the dorsal telencephalon. Development 129:3045-3054.

Tole S, Grove EA (2001) Detailed field pattern is intrinsic to the embryonic mouse hippocampus early in neurogenesis. J Neurosci 21:1580-1589.

Torii M, Matsuzaki F, Osumi N, Kaibuchi K, Nakamura S, Casarosa S, Guillemot F, Nakafuku M (1999) Transcription factors Mash-1 and Prox-1 delineate early steps in differentiation of neural stem cells in the developing central nervous system. Development 126:443-456.

Vyas A, Saha B, Lai E, Tole S (2003) Paleocortex is specified in mice in which dorsal telencephalic patterning is severely disrupted. J Comp Neurol 466:545-553.

Xuan S, Baptista CA, Balas G, Tao W, Soares VC, Lai E (1995) Winged helix transcription factor BF-1 is essential for the development of the cerebral hemispheres. Neuron 14:1141-1152. 